\title{
Nitrogen Dynamics in Soil as Influenced by Split Application of Organic Manures and Fertilizers under Sugarcane Grown on Calcareous Entisol of Bihar
}

\author{
Abhishek Ranjan ${ }^{1 *}$, C. K. Jha ${ }^{1}$, S. K. Thakur ${ }^{1}$, Shubham Singh ${ }^{2}$, \\ Vivek Kumar ${ }^{1}$ and Munmun Majhi ${ }^{3}$
}

${ }^{1}$ Department of Soil Science, RPCAU, Pusa (Samastipur), Bihar-848125, India
${ }^{2}$ Department of Soil Science, SNRM, CPGS-AS (CAU, Imphal), Umiam, Meghalaya-793103, India

${ }^{3}$ Department of Soil Science and Agricultural Chemistry, UBKV, Cooch Behar, West Bengal-736165, India

*Corresponding author

\section{A B S T R A C T}

Effect of nutrient management modules on nitrogen $(\mathrm{N})$ dynamics in sugarcane grown on a Calcareous entisol was studied during 2018-19. The experiment comprised of different levels of NPK fertilizers alone and in combination with Biocompost, Neem Cake Powder,

Keywords

Amino acid-N,

Hexoseamine-N, Hydrolysable $\mathrm{NH}_{4}{ }^{+}$

$\mathrm{N}, \mathrm{NO}_{3}^{-}-\mathrm{N}$,

Exchangeable

$\mathrm{NH}_{4}{ }^{+}-\mathrm{N}$

Article Info

Accepted:

17 June 2020

Available Online:

10 July 2020
Trichoderma inoculated trash and Rhizobium inoculated green gram applied at two different crop growth stage (Planting and Earthing Up) was laid out in RBD with three replications. Application of $25 \% \mathrm{~N}$ as inorganic fertilizer $+75 \% \mathrm{~N}$ through organics (Biocompost at planting and Neem cake at earthing up stage split equally) + Azotobacter and PSB significantly increased the organic $\mathrm{N}$ fractions viz., hydrolysable $\mathrm{NH}_{4}{ }^{+}-\mathrm{N}(108.3$ $\left.\mathrm{mg} \mathrm{kg}^{-1}\right)$, amino acid-N (111.2 $\left.\mathrm{mg} \mathrm{kg}^{-1}\right)$, Hexoseamine-N $\left(36 \mathrm{mg} \mathrm{kg}^{-1}\right)$ and Unidentified-N $\left(83.9 \mathrm{mg} \mathrm{kg}^{-1}\right)$. The mineral $\mathrm{N}\left(\mathrm{NO}_{3}^{-}-\mathrm{N}+\right.$ exchangeable $\left.\mathrm{NH}_{4}{ }^{+}-\mathrm{N}\right)$ content $\left(105.6 \mathrm{mg} \mathrm{kg}^{-1}\right)$ was significantly increased with the application of $50 \% \mathrm{~N}$ as inorganic fertilizer $+50 \% \mathrm{~N}$ through organics (Biocompost at planting and Neem cake at earthing up stage split equally) + Azotobacter and PSB. The highest contribution of inorganic was $17.65 \%$ in treatment receiving 50:50 ratio of inorganic and organic sources of nutrients whereas organic $\mathrm{N}$ fractions contribution to total $\mathrm{N}$ was highest in treatment receiving 25:75 ratio of inorganic and organic sources of nutrients and comparatively lower contribution of these fractions was recorded in control treatment. The mineralizable $\mathrm{N}$ was significantly correlated with all fractions of $\mathrm{N}$, except with hydrolysable unidentified-N and nonhydrolysable $\mathrm{N}$.

\section{Introduction}

Crops generally require sufficient quantities of macro nutrients particularly nitrogen during the majority of crop growth period.
Nitrogen $(\mathrm{N})$ is the most vital mineral nutrient which affects the growth and yield of crops. Being the $5^{\text {th }}$ most abundant element in the earth has an important role in increasing food production and sustaining the ever-increasing 
human and animal populations (Durani et al., 2016). Nitrogen often limits the primary production in agricultural and natural ecosystems (de Vries et al., 2006) therefore, its availability in adequate amount in plant available form is important for higher crop yields. The availability of nitrogen in soils is the key factor to determine the growth and yield of the crop. Its availability on earth is high ( $\square 5 \times 10^{9} \mathrm{Tg}$ ) but $<2 \%$ of it is available to organisms (Mackenzie, 2003). The available $\mathrm{N}$ in the soil plays a dominant role in the nutrition of crops.

The two chief forms of nitrogen in the soil are organic and inorganic nitrogen. Organic form of nitrogen accounts for more than $95 \%$ of total soil nitrogen and this form plays a significant role in $\mathrm{N}$ retention and transformation (Stevenson 1982). The availability of $\mathrm{N}$ to the growing plant is closely associated with depolymerization of the $\mathrm{N}$-containing constituents organic forms of nitrogen followed by its subsequent mineralization (Nannipieri and Eldor, 2009). Although depolymerization followed by mineralization takes place of the constituents of organic nitrogen but it becomes slowly available to crop plants due to its diverse nature (Stevenson, 1994). Also, the amount of inorganic form of nitrogen is not adequate to meet the needs of crops; consequently, some external source of readily available form of $\mathrm{N}$ in the form of fertilizers is added.

The classical theory of organic nitrogen availability for crops indicates its biochemical transformation to release inorganic $\mathrm{N}\left(\mathrm{NO}_{3}{ }^{-}\right.$ and $\mathrm{NH}_{4}{ }^{+}$), which is generally preferred for uptake. Incorporation of organic materials along with fertilizer- $\mathrm{N}$ affects the amount and distribution of organic $\mathrm{N}$-fraction viz. exchangeable $\mathrm{NH}_{4}{ }^{+}-\mathrm{N}$, hydrolysable $\mathrm{NH}_{4}{ }^{+}-\mathrm{N}$, hexoseamine- $\mathrm{N}$, amino acid-N, unidentified$\mathrm{N}$ and status of total-N (Santhy et al., 1998) and carbon pool considerably in soil (Sinha et $a l .$, 2017). The direct absorption of dissolved organic nitrogen (DON) is an important source of $\mathrm{N}$ nutrition, particularly in sandy soils low in $\mathrm{N}$-supplying capacity and in the absence of external chemical sources (Jones et al., 2005). Moreover, current evidence suggests that roots possess the capacity to take up low molecular weight DON, e.g., urea, amino acids, polyamines, and small polypeptides (Yu et al., 2002).

The inorganic and organic form of nitrogen exists in equilibrium and is affected by various abiotic and biotic processes. Currently, large amounts of urea are applied to farmland soil, resulting in nitrate leaching, increased soil acidity and other environmental issues (Guo et al., 2010). The alteration of soil properties leads to changes in $\mathrm{C}$ and $\mathrm{N}$ cycling, but the effects are inconsistent. Results from the long-term experiments envisaged that application of organic or chemical fertilizers alone failed to maintain the productivity of soil and sugarcane. The application of organic fertilizer in combination of chemical fertilizers not only helps sugarcane growing better, but also reduces the cost of cultivation, dependency on the chemical fertilizers, environmental pollution and soil health deterioration. With the raising apprehension on soil conservation and health in the context of depleting traditional organic manures, efforts are required to exploit the potentiality of easily available sources of organics effectively. Thus, this typical combination of nutrients under various nutritional modules proved better option for getting higher profitable cane and sugar yield besides improving soil health for sustaining sugarcane productivity.

Understanding the effect of manuring and fertilization on the $\mathrm{N}$ dynamics is prerequisite for precise $\mathrm{N}$ management under sugarcane based cropping system in Entisol of Bihar having high free $\mathrm{CaCO}_{3}$. Therefore, the present investigation was carried out to study the effect of different nutrient management 
modules on various $\mathrm{N}$ fractions and their relative contribution to yield of rice and $\mathrm{N}$ uptake.

\section{Materials and Methods}

A field experiment was conducted during 2018-19 at Crop Research Centre, Pusa farm, Dr. Rajendra Prasad Central Agricultural University, Bihar. The treatments comprised 7 different combinations of manures and fertilizers (Table 1). The recommended dose of fertilizers for sugarcane was 150: $85: 60 \mathrm{~kg}$ $\mathrm{N}, \mathrm{P}_{2} \mathrm{O}_{5}$ and $\mathrm{K}_{2} \mathrm{O}$ ha ${ }^{-1}$. In $\mathrm{T}_{2}$, Trichoderma inoculated sugarcane trash was spread 55 DAP. In $T_{3}$, green gram was sown as intercrop and was incorporated in soil at 60 DAP. In $\mathrm{T}_{4}, \mathrm{~T}_{5}, \mathrm{~T}_{6}$ and $\mathrm{T}_{7}$ neem cake powder was applied at earthing up stage at 120 DAP.

Experiment was laid out in randomized block design (RBD) with three replications. Soil samples were collected from $0-15 \mathrm{~cm}$ after harvest of sugarcane crop. Collected soil samples were dried in shade and ground with the help of wooden pestle and mortar. These ground samples were then passed through a 2 $\mathrm{mm}$ sieve and were mixed thoroughly and stored in polythene bags, properly labeled and preserved for subsequent analysis. fractions of organic-N and total- $\mathrm{N}$ in soil samples were estimated as per the methods suggested by Bremner (1965a,b). these fractions were determined: Inorganic-N (2 N KCL extract); total hydrolysable- $\mathrm{N}$ (digestion of residue after 2 KCL extract in $6 \mathrm{~N}$ HCL); hydrolysable $\mathrm{NH}_{4}{ }^{+}-\mathrm{N}$ (direct distillation of 25 $\mathrm{mL}$ of neutralized $6 \mathrm{~N}$ HCL extract); hexoseamine- $\mathrm{N}$ and hydrolysable $\mathrm{NH}_{4}{ }^{+}-\mathrm{N}$ (direct distillation of $25 \mathrm{ml}$ of neutralized $6 \mathrm{~N}$ HCL extract after addition of $25 \mathrm{~mL}$ of phosphate borate buffer to give $\mathrm{pH} 11.2$ ); (hexoseamine- $\mathrm{N}$ was calculated as difference); amino acid-N (ninhydrin method); unidentified hydrolysable (total hydrolysable- $\mathrm{N}$-some of hydrolysable $\mathrm{NH}_{4}{ }^{+}-\mathrm{N}$ hexoseamine- $\mathrm{N}$ and amino acid-N); non-hydrolysable-N (determined by the same procedure mentioned earlier as in the case of total soil-N determination except that salicylic acid was not included in the digestion); and total-N (modified Kjeldahl method according to Bremner 1965a). The data were analyzed statistically as per Panse and Sukhatme (1971).

Table.1 Treatment details of the experiment

\begin{tabular}{|l|l|}
\hline Treatments & \multicolumn{1}{c|}{ Treatments Detail } \\
\hline $\mathbf{T}_{\mathbf{1}}$ & $100 \% \mathrm{NPK}-\mathrm{RDF}(\mathrm{Control})$ \\
\hline $\mathbf{T}_{\mathbf{2}}$ & $100 \% \mathrm{~N}$ as IF + Organic mulching with ST @ $6 \mathrm{t} \mathrm{ha}^{-1}+$ Trichoderma \\
\hline $\mathbf{T}_{\mathbf{3}}$ & $100 \% \mathrm{~N}$ as IF + GM with green gram as intercrop inoculated with Rhizobium \\
\hline $\mathbf{T}_{\mathbf{4}}$ & $25 \% \mathrm{~N}$ as IF + 75\% N through organics; BC, PL + NC, ER (1/2 each) + Azophos \\
\hline $\mathbf{T}_{\mathbf{5}}$ & $50 \% \mathrm{~N}$ as IF + 50\% N through organics; BC, PL + NC ER (1/2 each) + Azophos \\
\hline $\mathbf{T}_{\mathbf{6}}$ & $75 \% \mathrm{~N}$ as IF + 25\% N through organics; BC, PL + NC, ER (1/2 each) + Azophos \\
\hline $\mathbf{T}_{\mathbf{7}}$ & $100 \% \mathrm{~N}$ through organics; BC, PL + NC, ER (1/2 each) + Azophos \\
\hline
\end{tabular}

$\mathrm{RDF}=$ Recommended Dose of Fertilizer, $\mathrm{IF}=$ Inorganic fertilizer, $\mathrm{ST}=$ Sugarcane Trash, $\mathrm{BC}=\mathrm{Biocompost}, \mathrm{PL}=$ Planting, NC= Neem Cake, ER= Earthing up, Azophos = Azotobacter + Phosphate solubilising Bacteria 


\section{Results and Discussion}

\section{Soil Inorganic Nitrogen}

The distribution of soil inorganic nitrogen in the surface soil depth $(0-15 \mathrm{~cm})$ is presented in table 2.The highest value of $\mathrm{NO}_{3}{ }^{-} \mathrm{N}$ contributed $3 \%$ of total- $\mathrm{N}$ was observed in treatment $\mathrm{T}_{1}\left(16.5 \mathrm{mg} \mathrm{kg}^{-1}\right)$ receiving $100 \%$ NPK and being lowest in treatment $\mathrm{T}_{7}$ (13.2 $\mathrm{mg} \mathrm{kg}^{-1}$ ) receiving $100 \% \mathrm{~N}$ through organics (fig 1). The result indicated that application of organic manure reduced $\mathrm{NO}_{3}{ }^{-}-\mathrm{N}$ content in soil. This might be attributed to the denitrification and losses of $\mathrm{NO}_{3}{ }^{-}{ }^{-} \mathrm{N}$. Treatment $\mathrm{T}_{5}$ (90.6 $\mathrm{mg} \mathrm{kg}^{-1}$ ) gave highest value of $\mathrm{NH}_{4}{ }^{+}-\mathrm{N}$ which received $\mathrm{N}$ in 50:50 ratio from inorganic and organic sources along with biofertilizers and lowest was recorded in $\mathrm{T}_{1}\left(56.8 \mathrm{mg} \mathrm{kg}^{-1}\right)$ receiving $100 \%$ $\mathrm{RDF}$ in inorganic form. The increase in $\mathrm{NH}_{4}{ }^{+}$ $\mathrm{N}$ over control was followed the decreasing order $\mathrm{T}_{5}\left(90.6 \mathrm{mg} \mathrm{kg}^{-1}\right)>\mathrm{T}_{4}\left(84.6 \mathrm{mg} \mathrm{kg}^{-1}\right)>$ $\mathrm{T}_{6}\left(74.8 \mathrm{mg} \mathrm{kg}^{-1}\right)>\mathrm{T}_{3}\left(66.4 \mathrm{mg} \mathrm{kg}^{-1}\right)>\mathrm{T}_{2}$ $\left(60.8 \mathrm{mg} \mathrm{kg}^{-1}\right)>\mathrm{T}_{7}\left(60.0 \mathrm{mg} \mathrm{kg}^{-1}\right)$. The $\mathrm{NH}_{4}{ }^{+}-$ $\mathrm{N}$ contributed $13 \%$ to total $\mathrm{N}$. Combined application of inorganic fertilizers along with organic manures increased both the inorganic forms of $\mathrm{N}$ over their individual application. Manivannan and Sriramachandrasekharan (2009) also reported increase in inorganic N with integration of manures and fertilizers.

\section{Soil organic nitrogen}

The distribution of nitrogen in hydrolyzable$\mathrm{N}$ (HN) and non-hydrolyzable-N (NHN) fractions of soil organic nitrogen in the surface soil depth $(0-15 \mathrm{~cm})$ is presented in table 2 and the contribution of different forms of soil organic nitrogen to total soil nitrogen is presented in figure 1. Total hydrolysable-N fraction contributed maximum $(55 \%)$ towards total $\mathrm{N}$ in soil. On an average, different component of total hydrolysable-N viz., hydrolysable $\mathrm{NH}_{4}{ }^{+}-\mathrm{N}$, hexoseamine- $\mathrm{N}$, amino acid- $\mathrm{N}$ and unidentified-N contributed 29.0,
$9.3,35.4$ and $26.3 \%$ respectively to total hydrolysable $\mathrm{N}$. The maximum value of amino acid-N was obtained in treatment $\mathrm{T}_{5}$ (112.6 $\mathrm{mg} \mathrm{kg}^{-1}$ ) receiving $50 \% \mathrm{~N}$ through inorganic fertilizer $+50 \% \mathrm{~N}$ as organic manure along with biofertilizers while, lowest value of $94.9 \mathrm{mg} \mathrm{kg}^{-1}$ was recorded in control (100\% RDF). However, combined application of organic + inorganic nutrient sources did not produce any significant difference and therefore, treatments $\mathrm{T}_{2}\left(104.7 \mathrm{mg} \mathrm{kg}^{-1}\right), \mathrm{T}_{4}$ (111.2 $\left.\mathrm{mg} \mathrm{kg}^{-1}\right), \mathrm{T}_{5}\left(112.6 \mathrm{mg} \mathrm{kg}^{-1}\right), \mathrm{T}_{6}(109.2$ $\left.\mathrm{mg} \mathrm{kg}{ }^{-1}\right)$ and $\mathrm{T}_{7}\left(103.7 \mathrm{mg} \mathrm{kg}^{-1}\right)$ receiving combination of organic + inorganic nutrient sources were at par with each other.

The variation in hydolysable $\mathrm{NH}_{4}{ }^{+}-\mathrm{N}$ was found to be significantly affected (68.6 $108.3 \mathrm{mg} \mathrm{kg}^{-1}$ ) due to different nutrient combination. The maximum hydrolysable $\mathrm{NH}_{4}{ }^{+}-\mathrm{N}$ was found for treatment $\mathrm{T}_{4}(108.3 \mathrm{mg}$ $\mathrm{kg}-1$ ) receiving 75 per cent $\mathrm{N}$ through organics (biocompost + neem cake) along with biofertilizers. However, treatments $\mathrm{T}_{4}$ (108.3 $\left.\mathrm{mg} \mathrm{kg}^{-1}\right), \mathrm{T}_{5}\left(102.2 \mathrm{mg} \mathrm{kg}^{-1}\right) \mathrm{T}_{6}(95.1$ $\left.\mathrm{mg} \mathrm{kg}{ }^{-1}\right)$ and $\mathrm{T}_{7}\left(82.1 \mathrm{mg} \mathrm{kg}^{-1}\right)$ was found to be at par with each other and significantly superior over treatments $T_{1}\left(68.6 \mathrm{mg} \mathrm{kg}^{-1}\right), \mathrm{T}_{2}$ (73.5 $\mathrm{mg} \mathrm{kg}^{-1}$ ) and $\mathrm{T}_{3}\left(74.2 \mathrm{mg} \mathrm{kg}^{-1}\right)$. The extent of increase in hydrolysable $\mathrm{NH}_{4}{ }^{+}-\mathrm{N}$ due to application of different nutrient was $6.67,7.55,16.44,27.86,32.87$ and $36.66 \%$ in treatments $\mathrm{T}_{2}, \mathrm{~T}_{3}, \quad \mathrm{~T}_{7}, \mathrm{~T}_{6}, \mathrm{~T}_{5}$ and $\mathrm{T}_{4}$ respectively over control.

The unidentified hydolysable-N contributed $26.3 \%$ to total hydrolysable- $\mathrm{N}$ fraction. It was found highest for treatment $\mathrm{T}_{5}\left(84.3 \mathrm{mg} \mathrm{kg}^{-1}\right)$ receiving $50 \% \mathrm{~N}$ through inorganic fertilizer $+50 \% \mathrm{~N}$ through biocompost + neem cake along with biofertilizer with an increment of $5.1 \%$ over control $\left(\mathrm{T}_{1} ; 79.8 \mathrm{mg} \mathrm{kg}^{-1}\right)$. The data further revealed that lowest value of unidentified hydolysable-N was recorded in treatment $\mathrm{T}_{3}\left(73.8 \mathrm{mg} \mathrm{kg}^{-1}\right)$ receiving $100 \%$ $\mathrm{NPK}+$ Rhizobium inoculated green gram as green manure. 
Hexoseamine-N (9.3\%) contributed lowest to total hydrolysable-N fraction. Highest value was obtained for treatment $\mathrm{T}_{4}\left(36.0 \mathrm{mg} \mathrm{kg}{ }^{-1}\right)$ followed by $\mathrm{T}_{5}\left(32.1 \mathrm{mg} \mathrm{kg}^{-1}\right) \mathrm{T}_{6}\left(27.7 \mathrm{mg} \mathrm{kg}^{-}\right.$ $\left.{ }^{1}\right) \mathrm{T}_{2}\left(25.8 \mathrm{mg} \mathrm{kg}^{-1}\right), \mathrm{T}_{7}\left(25.2 \mathrm{mg} \mathrm{kg}^{-1}\right)$ and $\mathrm{T}_{3}$ $\left(24.5 \mathrm{mg} \mathrm{kg}^{-1}\right)$ which were significantly higher over control $\left(\mathrm{T}_{1} ; 21.7 \mathrm{mg} \mathrm{kg}^{-1}\right)$.

From the fig 1 it can be inferred that nonhydrolysable-N contributed $29 \%$ to total-N. Non-hydrolysable-N fraction varied significantly from $140.5-164.1 \mathrm{mg} \mathrm{kg}^{-1}$ due to different nutrient management practices. The extent of augmentation due to different treatment over control was $10.39 \%\left(\mathrm{~T}_{2} \& \mathrm{~T}_{3}\right)$, $10.63 \%\left(\mathrm{~T}_{6}\right), 12.08 \%\left(\mathrm{~T}_{7}\right), 13.11 \%\left(\mathrm{~T}_{5}\right)$ and $14.38 \%\left(\mathrm{~T}_{4}\right)$. Highest value of nonhydrolysable $\mathrm{N}$ was recorded in treatment $\mathrm{T}_{4}$ receiving $75 \% \mathrm{~N}$ through organics $+25 \% \mathrm{~N}$ through inorganics while lowest in control (140.5 $\mathrm{mg} \mathrm{kg}^{-1}$ ) receiving 100\% NPK through inorganic fertilizers.

\section{Total-N}

Total-N calculated as sum of $\mathrm{NO}_{3}{ }^{-} \mathrm{N}+$ Exchangeable $\mathrm{NH}_{4}{ }^{+}-\mathrm{N}+$ Total hydrolysable$\mathrm{N}+$ Non-hydolysable-N was found to be highest for treatment $\mathrm{T}_{4}\left(603.1 \mathrm{mg} \mathrm{kg} \mathrm{kg}^{-1}\right)$ receiving $75 \% \mathrm{~N}$ through organics $+25 \% \mathrm{~N}$ through inorganics. However, treatments $\mathrm{T}_{4}$ (603.1 $\left.\mathrm{mg} \mathrm{kg}^{-1}\right), \mathrm{T}_{5}\left(598.5 \mathrm{mg} \mathrm{kg}^{-1}\right)$ and $\mathrm{T}_{6}$ (554.4 $\mathrm{mg} \mathrm{kg}^{-1}$ ) were at par with each other and significantly superior over rest other treatments. The extent of increment in total-N due to application of INM modules were 6.32, $6.70,7.35,13.63,20.0$ and $20.61 \%$ in treatments $\mathrm{T}_{3}, \quad \mathrm{~T}_{7}, \mathrm{~T}_{2}, \mathrm{~T}_{6}, \mathrm{~T}_{5}$ and $\mathrm{T}_{4}$ respectively over control (100\% NPK).

Application of mineral fertilizers alone or in combination with organic manures might have significantly increased concentration of mineral $\mathrm{N}\left(\mathrm{NO}_{3}{ }^{-}-\mathrm{N}+\mathrm{NH}_{4}{ }^{+}-\mathrm{N}\right)$ in the soil. The lower mineral $\mathrm{N}$ in control plot as compared to organic plot might be due to higher losses, such as volatilization, leaching and denitrification. The effect of mineral fertilizers and manures on the interplay between different fractions of organic $\mathrm{N}$ is a prerequisite for managing $\mathrm{N}$ inputs in a given soil. The changes in these fractions provided an assessment that additional $\mathrm{N}$ provided by organic fertilization was primarily concentrated in hydrolysable organic $\mathrm{N}$ fractions, which are considered the major source of plant available $\mathrm{N}$.

The increase in hydrolysable $\mathrm{N}$ fraction with combined application of organic manures and inorganic fertilizer might be due to the mineralization and release of $\mathrm{N}$ contained in manure on their decomposition caused by a favourable environment and presence of consortium of microbes. Among the hydrolysable fraction, increase in hydrolysable $\mathrm{NH}_{4}{ }^{+}-\mathrm{N}$ may be attributed to decomposition of proteins, nucleic acids and large number of other organic compounds, while higher amino acid-N might be due to rate of mineralization of the protein fraction of added manures. Also, at higher level of organic manure application, the decrease in non-hydrolysable fraction of $\mathrm{N}$ may be ascribed to its conversion into hydrolysable$\mathrm{N}$.

The application of inorganic fertilizer and organic manure resulted increase in soil organic carbon which is turn increased the non hydrolysable-N content (Durani et al., 2016). Similar findings were elucidated by Santhy et al., (1998), Eagle et al., (2001), Sarawad and Singh (2005), Zhong et al., (2015) and Sinha et al., (2017) 
Table.2 Effect of INM modules on soil nitrogen fractions after sugarcane harvest

\begin{tabular}{|c|c|c|c|c|c|c|c|c|c|}
\hline \multirow[t]{4}{*}{ Treatments } & \multicolumn{8}{|c|}{$\mathrm{N}$ fractions $\left(\mathrm{mg} \mathrm{kg}^{-1}\right)$} & \multirow{4}{*}{$\begin{array}{c}\text { Total } \\
\mathbf{N}\end{array}$} \\
\hline & \multicolumn{2}{|c|}{ Soil Inorganic $\mathbf{N}$} & \multirow{2}{*}{\multicolumn{6}{|c|}{$\begin{array}{c}\text { Soil Organic N } \\
\text { Hydrolysable N }\end{array}$}} & \\
\hline & \multirow{2}{*}{$\begin{array}{c}\mathrm{NO}_{3}^{-}- \\
\mathrm{N}\end{array}$} & \multirow{2}{*}{$\begin{array}{c}\text { Exch. } \\
\mathrm{NH}_{4}{ }^{+}- \\
\mathbf{N}\end{array}$} & & & & & & & \\
\hline & & & $\begin{array}{l}\mathrm{NH}_{4}{ }^{+}- \\
\mathrm{N}\end{array}$ & $\begin{array}{l}\text { Hexose- } \\
\text { amine-N }\end{array}$ & $\begin{array}{l}\text { Amino } \\
\text { acid-N }\end{array}$ & Unidentified-N & $\begin{array}{c}\text { Total } \\
\text { Hydrolysable-N }\end{array}$ & $\begin{array}{c}\text { Non } \\
\text { Hydrolysable-N }\end{array}$ & \\
\hline $\mathbf{T}_{1}$ & 16.5 & 56.8 & 68.6 & 21.7 & 94.9 & 79.8 & 265.0 & 140.5 & 478.8 \\
\hline $\mathbf{T}_{2}$ & 15.2 & 60.8 & 73.5 & 25.8 & 104.7 & 80.0 & 284.0 & 156.8 & 516.8 \\
\hline $\mathbf{T}_{\mathbf{3}}$ & 15.8 & 66.4 & 74.2 & 24.5 & 99.5 & 73.8 & 272.0 & 156.9 & 511.1 \\
\hline $\mathbf{T}_{4}$ & 14.7 & 84.6 & 108.3 & 36.0 & 111.2 & 83.9 & 339.7 & 164.1 & 603.1 \\
\hline $\mathbf{T}_{5}$ & 15.0 & 90.6 & 102.2 & 32.1 & 112.6 & 84.3 & 331.2 & 161.7 & 598.5 \\
\hline $\mathbf{T}_{6}$ & 14.8 & 74.8 & 95.1 & 27.7 & 109.2 & 75.6 & 307.6 & 157.2 & 554.4 \\
\hline $\mathbf{T}_{7}$ & 13.2 & 60.0 & 82.1 & 25.2 & 103.7 & 69.2 & 280.2 & 159.8 & 513.2 \\
\hline $\operatorname{SEm}( \pm)$ & 0.5 & 1.8 & 2.2 & 0.6 & 2.1 & 2.3 & 6.8 & 4.4 & 13.1 \\
\hline $\operatorname{LSD}_{(0.05)}$ & 1.5 & 5.4 & 6.7 & 1.9 & 6.3 & 6.7 & 20.9 & 13.6 & 40.4 \\
\hline
\end{tabular}

Table.3 Correlation coefficient (r) among different fractions of soil nitrogen

\begin{tabular}{|c|c|c|c|c|c|c|c|c|c|}
\hline & \multirow[t]{2}{*}{$\mathrm{NO}_{3}{ }^{-}-\mathrm{N}$} & \multirow{2}{*}{$\underset{\mathrm{N}}{\mathrm{Ex}-\mathrm{NH}_{4}{ }^{+}-}$} & \multicolumn{5}{|c|}{ Hydrolysable-N } & \multirow{2}{*}{$\begin{array}{c}\text { Non- } \\
\text { Hydroly- } \\
\text { sable-N }\end{array}$} & \multirow[t]{2}{*}{ Total-N } \\
\hline & & & $\begin{array}{c}\text { Hydroly- } \\
\text { Sable } \\
\mathrm{NH}_{4}{ }^{+}-\mathrm{N}\end{array}$ & $\begin{array}{l}\text { Hexose- } \\
\text { amine- } \\
\mathbf{N}\end{array}$ & $\begin{array}{l}\text { Amino } \\
\text { acid-N }\end{array}$ & $\begin{array}{l}\text { Unidentified- } \\
\mathbf{N}\end{array}$ & $\begin{array}{c}\text { Total } \\
\text { Hydroly- } \\
\text { sable-N }\end{array}$ & & \\
\hline $\mathrm{Ex}-\mathrm{NH}_{4}{ }^{+}-\mathrm{N}$ & -0.149 & 1 & & & & & & & \\
\hline Hydrolysable $\mathrm{NH}_{4}{ }^{+}-\mathrm{N}$ & -0.414 & $0.921 * *$ & 1 & & & & & & \\
\hline Hexoseamine-N & -0.329 & $0.896 * *$ & $0.944 * *$ & 1 & & & & & \\
\hline Unidentified-N & 0.414 & 0.615 & 0.472 & 0.611 & 0.428 & 1 & & & \\
\hline Total Hydrolysable-N & -0.306 & $0.941 * *$ & $0.975 * *$ & $0.974 * *$ & $0.929 * *$ & 0.634 & 1 & & \\
\hline Non-Hydrolysable-N & -0.680 & 0.655 & 0.722 & 0.763* & 0.828* & 0.075 & 0.703 & 1 & \\
\hline Total-N & -0.320 & $0.965 * *$ & $0.969 * *$ & $0.970 * *$ & $0.940 * *$ & 0.586 & $0.990 * *$ & $0.766 *$ & 1 \\
\hline
\end{tabular}

*Correlation is significant at the 0.05 level; $\quad{ }^{* *}$ Correlation is significant at the 0.01 level. 
Fig.1 Percent contribution of different fractions of $\mathrm{N}$ to total $\mathrm{N}$

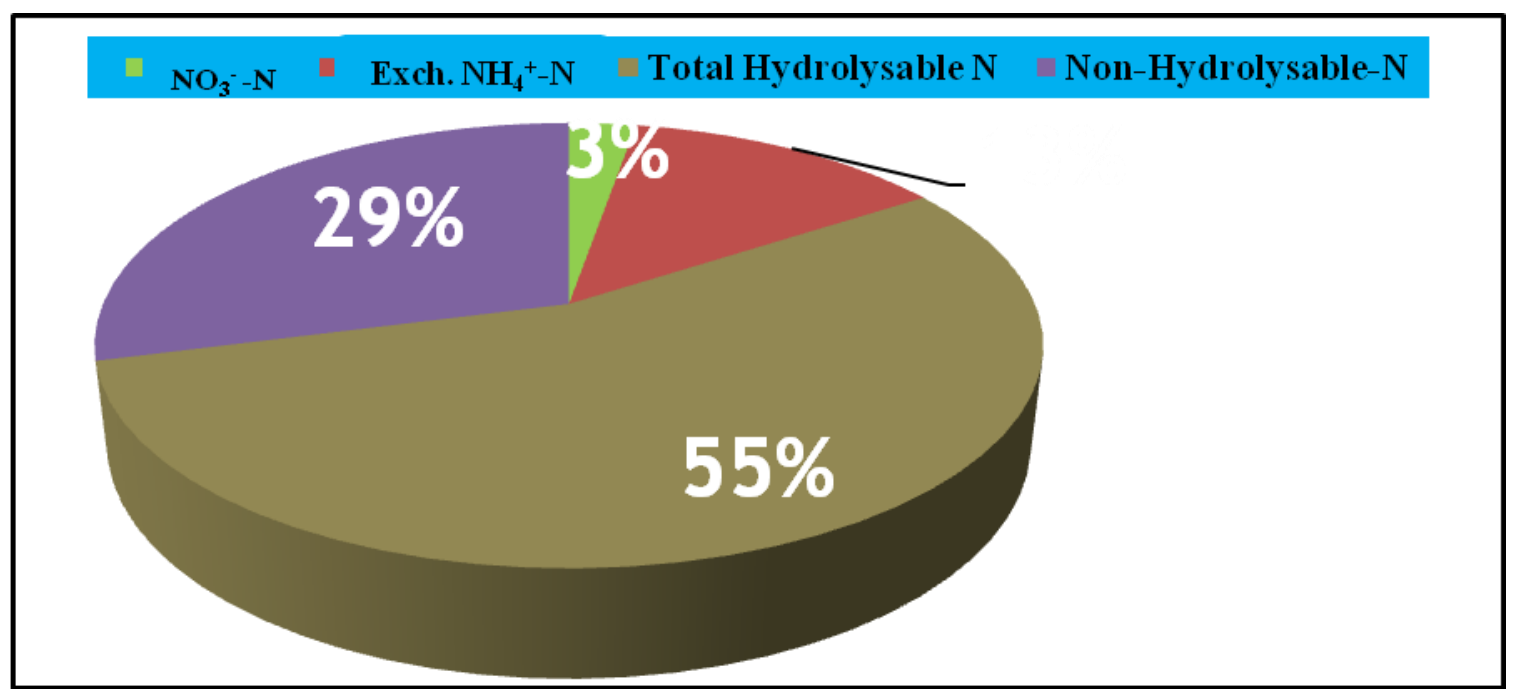

Fig.2 Percent contribution of different hydrolysable fraction of $\mathrm{N}$ to total Hydrolysable-N

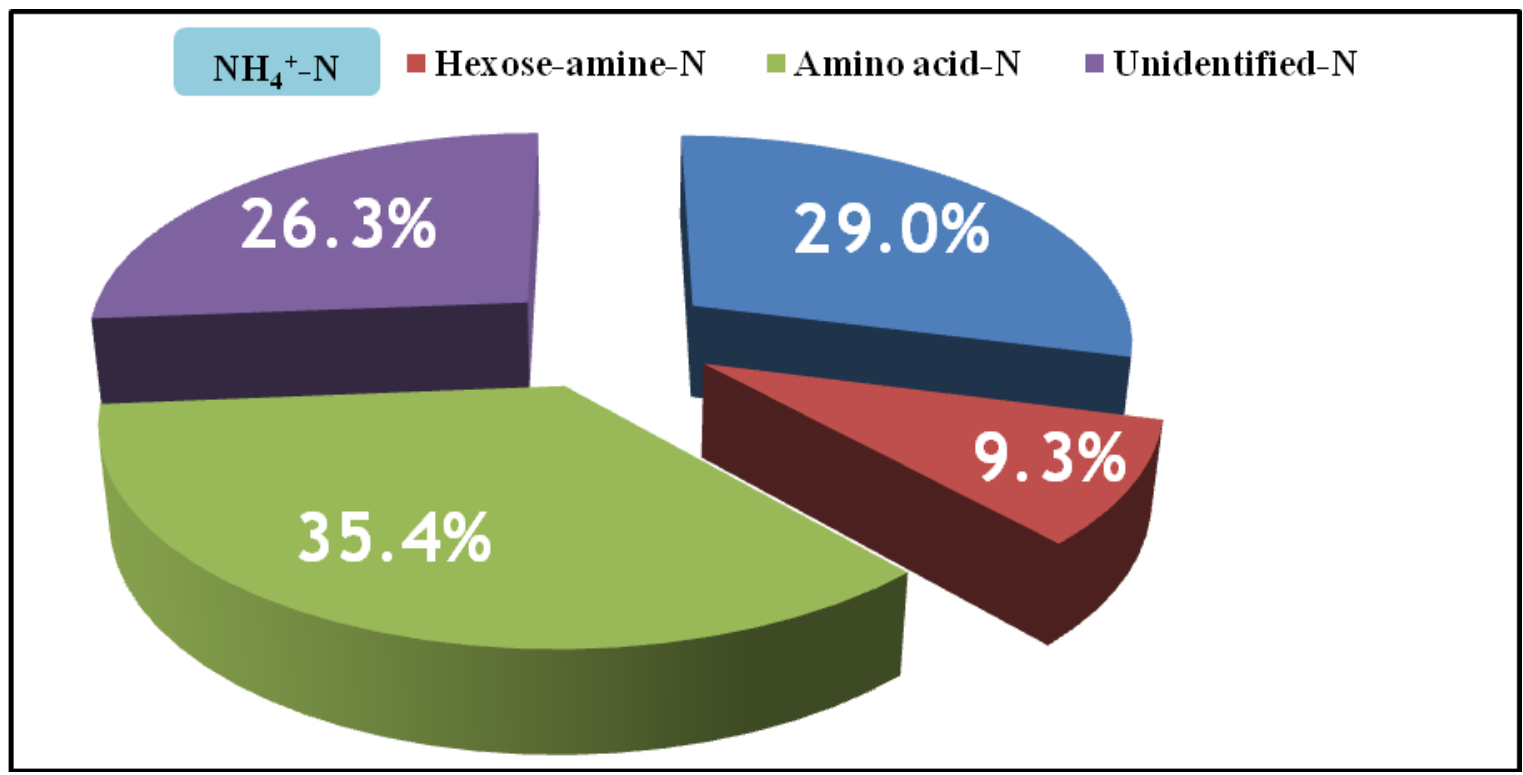

Correlation coefficient (r) among different fractions of soil nitrogen

The result presented in table 3 indicated that total-N was highly positively and significantly correlated with exchangeable $\mathrm{NH}_{4}{ }^{+}-\mathrm{N}$ $\left(\mathrm{r}=0.965^{* *}\right), \quad$ hydrolysable $\quad \mathrm{NH}_{4}{ }^{+}-\mathrm{N}$ $\left(\mathrm{r}=0.969^{* *}\right), \quad$ hexoseamine- $\mathrm{N} \quad\left(\mathrm{r}=0.970^{* *}\right)$, amino acid-N $(\mathrm{r}=0.940 * *)$ and total hydrolysable-N $(\mathrm{r}=0.990 * *)$, while the value of correlation coefficient for nonhydrolysable-N was $\left(\mathrm{r}=0.766^{*}\right)$. Also, no significant correlation was found between total-N and $\mathrm{NO}_{3}{ }^{-} \mathrm{N}$ and unidentified-N. The correlation coefficient value for nonhydrolysable-N with amino acid-N and hexoseamine-N was $0.828^{*}$ and $0.763^{*}$ respectively, while no correlation was found with exchangeable $\mathrm{NH}_{4}{ }^{+}-\mathrm{N} \quad(\mathrm{r}=0.655)$, hydrolysable- $\mathrm{NH}_{4}{ }^{+}-\mathrm{N}(\mathrm{r}=0.722), \mathrm{NO}_{3}{ }^{-} \mathrm{N}(\mathrm{r}=-$ 
0.680), unidentified-N ( $\mathrm{r}=0.075)$, and total hydrolysable-N $\quad(\mathrm{r}=0.703) . \quad$ Total hydrolysable-N had highly positive and significant correlation with all fractions except $\mathrm{NO}_{3}^{-}-\mathrm{N}$ and unidentified-N. The correlation value for total hydrolysable-N with exchangeable $\mathrm{NH}_{4}{ }^{+}-\mathrm{N}$, hydrolysable $\mathrm{NH}_{4}{ }^{+}-\mathrm{N}$, hexoseamine- $\mathrm{N}$ and amino acid-N was found $0.941^{* *}, 0.975^{* *}, 0.974^{* *}$, and $0.929 * *$ respectively. Amino acid-N was positively and significantly correlated with exchangeable $\quad \mathrm{NH}_{4}{ }^{+}-\mathrm{N} \quad(\mathrm{r}=0.862 *)$, hydrolysable $\quad \mathrm{NH}_{4}{ }^{+}-\mathrm{N} \quad(\mathrm{r}=0.914 * *)$ and hexoseamine- $\mathrm{N} \quad\left(\mathrm{r}=0.883^{* *}\right)$. It was also observed that hexoseamine-N showed highly positive and significant correlation with exchangeable $\mathrm{NH}_{4}{ }^{+}-\mathrm{N} \quad\left(0.896^{* *}\right)$ and hydrolysable $\mathrm{NH}_{4}{ }^{+}-\mathrm{N} \quad(0.944 * *)$ Also, hydrolysable $\mathrm{NH}_{4}{ }^{+}-\mathrm{N}$ was positively and significantly correlated with exchangeable $\mathrm{NH}_{4}{ }^{+}-\mathrm{N}\left(\mathrm{r}=0.921^{* *}\right)$. The data indicated that since $\mathrm{NO}_{3}{ }^{-} \mathrm{N}$ failed to produce significant correlation with any of the other $\mathrm{N}$ fraction and this fraction is not in equilibrium with other nitrogen fractions of soil. This might be due to highly mobile nature of $\mathrm{NO}_{3}{ }^{-} \mathrm{N}$. The other fractions were in dynamic equilibrium indicating interchangeable behavior of these $\mathrm{N}$ Fractions. The present findings are in accordance with Umesh et al., (2014). Schomberg et al., (2009), Durani et al., (2016), and Liu et al., (2018) reported similar findings.

The above study conducted in calcareous soil of Bihar revealed that due to integrated application of organic and inorganic sources different fractions of soil $\mathrm{N} v i z ., \mathrm{NO}_{3}{ }^{-}-\mathrm{N}$, exchangeable $\mathrm{NH}_{4}{ }^{+}-\mathrm{N}$, total hydrolysable- $\mathrm{N}$, non-hydolysable- $\mathrm{N}$ and total-N varied significantly. The contribution of different fractions of soil $\mathrm{N}$ to total- $\mathrm{N}$ was $3 \%$ for $\mathrm{NO}_{3}{ }^{-}$ $-\mathrm{N}, 13 \%$ for exchangeable $\mathrm{NH}_{4}{ }^{+} \mathrm{N}, 55 \%$ for total hydrolysable-N and $29 \%$ for nonhydolysable-N. The total-N was highly positively and significantly correlated with exchangeable $\mathrm{NH}_{4}{ }^{+}-\mathrm{N}$, hydrolysable $\mathrm{NH}_{4}{ }^{+}-\mathrm{N}$, hexoseamine- $\mathrm{N}$, amino acid- $\mathrm{N}$ and total hydrolysable-N. The $\mathrm{NO}_{3}{ }^{-}-\mathrm{N}$ did not produce significant correlation with any of the other $\mathrm{N}$ fractions which indicated that $\mathrm{NO}_{3}{ }^{-} \mathrm{N}$ fraction was not in equilibrium with other soil nitrogen fractions. The maximum increment in cane yield by $20.67 \%$ was recorded in treatment $\mathrm{T}_{5}$ receiving 50 per cent $\mathrm{N}$ through inorganic +50 per cent $\mathrm{N}$ through organic fertilizer along with biofertilizer and lowest in $\mathrm{T}_{1}$ receiving $100 \%$ NPK (control). Application of $100 \% \mathrm{~N}$ through organics resulted cane yield similar to application of recommended dose of fertilizer (100\% NPK). Nitrogen uptake followed the similar trend of cane yield.

\section{References}

Bremner, J.M. (1965a). In "Soil Nitrogen" pp. 9399 (eds. W.V. Bartholomew and F.E. Clark). American Society of Agronomy. Madison, Winconsin, USA.

Bremner, J.M. (1965b). Studies of soil humic acid-I. the chemical nature of humic nitrogen. Journal of the agricultural sciences. 46:247.

De Vries, W., G. J. Reinds, P. Gundersen, and H. Sterba. (2006). The impact of nitrogen deposition on carbon sequestration in European forests and forest soils. Global Change Biology 12:1151-73. doi:10.1111/j.1365-2486.2006.01151.x.

Durani, A., Brar, B.S. and Dheri, G.S. (2016). Soil nitrogen fractions in relation to rice-wheat productivity: effects of long-term application of mineral fertilizers and organic manures. Journal of Crop Improvement 30(4): 399420.

Eagle, A.J., Bird, J.A., Hill, J.E., Howarth, W.R. and Vankessel, C. (2001). Nitrogen dynamics and fertilizer $\mathrm{N}$ use efficiency in rice following straw incorporation and winter flooding. Agronomy Journal. 93:134-1354.

Guo, J.H., Liu, X.J., Zhang, Y., Shen, J.L., Han, W.X., Zhang, W.F., Christie, P., Goulding, K.W.T., Vitousek, P.M., Zhang, F.S. (2010). Significant acidification in major Chinese croplands. Science. 327:1008-1010. 
Jones, D.L., Healey, J.R., Willett, V.B., Farrar, J.F. and Hodge. A. (2005). Dissolved organic nitrogen uptake by plants-An important $\mathrm{N}$ uptake pathway. Soil Biology and Biochemistry 37:413-23.

Liu, D., Huang, Y., Yan, H., Zhao, T. and An, Shaoshan. (2018). Dynamics of soil nitrogen fractions and their relationship with soil microbial communities in two forest species of northern China. PLos ONE. 13(5):1-19.

Mackenzie, F. (2003). Our changing planet: An introduction to earth system science and global environmental change, 3rd ed., xi. Upper Saddle River, NJ: Prentice-Hall.

Manivannan, R., and M. Sriramachandrasekharan. (2009). Response of lowland rice to addition of organics and mineral $\mathrm{N}$ grown on Typic Haplusterts soil. Journal of Applied Sciences Research. 5(11):1988-1991.

Nannipieri, P. and Eldor, P. (2009). The chemical and functional characterization of soil $\mathrm{N}$ and its biotic components. Soil Biologic Biochemical 41:2357-2369.

Panse, V.G. and Sukhatme, P.V. (1971) Statistical Methods for Agricultural Workers. ICAR, New Delhi.

Santhy, P., Shankar, J.S., Muthuvel, P. and Selvi, D. (1998). Long term fertilizer experiment status of N, P and K fractions in soil. Journal of the Indian Society of Soil Science.4:395398.

Sarawad, I.M. and Singh, D. (2005). Soil Nitrogen fractions under maize-wheat-cowpea cropping sequence under long-term fertilizer use. Karnataka J. Agric. Sci. 17(4):705-711.

Schomberg, H.H., Wietholter, S., Reeves, D.W., Cabrera, M.L., Fisher, D.S., Endale, D.M., Novak, J.M., Balkcom, K.S., Raper, R.L., Kitchen, N.R., Locke, M.A., Potter, K.N., Schwartz, R.C., Truman, C.C. and Tyler,
D.D. (2009). Assessing Indices for Predicting Potential Nitrogen Mineralization in Soils under Different Management Systems. Soil Science Society of America Journal. 73(5):1575-1586.

Sinha, S.K, Jha, C.K., Kumar, V. and Pandey, S.S. (2017). Yield and soil organic carbon pool in relation to soil fertility of sugarcane (Saccharum species hybrid complex) plantratoon system under integrated nutrient management. Indian Journal of Agronomy. 62(1):25-30.

Stevenson, F. J. 1982. Organic forms of soil nitrogen in agricultural soils. Agronomy 22 Madison, WI: ASA, CSA, SSSA.

Stevenson, F.J. 1994. Humus chemistry: Genesis, composition, reactions. New York: John Wiley \& Sons.

Umesh, U.N., Kumar, V., Prasad, R.K., Singh, K.D.N. and Singh, A.P. (2014). Effect of integrated use of inorganic and organic materials on the distribution of different forms of nitrogen in soil and their influence on sugarcane yield and nutrient uptake. Journal of the Indian Society of Soil Science. 62(3):209-215.

Yu, Z., Q. Zhang, T. Kraus, R. Dahlgren, C. Anastasio, and R. Zasoski. (2002). Contribution of amino compounds to dissolved organic nitrogen in forest soils. Biogeochemistry 61:173-98. doi:10.1023/A:1020221528515.

Zhong, Y., Yan, W. and Shangguan, Z. (2015). Soil carbon and nitrogen fractions in the soil profile and their response to long-term nitrogen fertilization in a wheat field. Catena. 135:38-46.

\section{How to cite this article:}

Abhishek Ranjan, C. K. Jha, S. K. Thakur, Shubham Singh, Vivek Kumar and Munmun Majhi. 2020. Nitrogen Dynamics in Soil as Influenced by Split Application of Organic Manures and Fertilizers under Sugarcane Grown on Calcareous Entisol of Bihar. Int.J.Curr.Microbiol.App.Sci. 9(07): 1984-1992. doi: https://doi.org/10.20546/ijcmas.2020.907.227 